\title{
Studies on gastroprotective activity of ethyl acetate leave fraction obtained from Canthium coromandelicum (Burm.f.) Alston in albino rats
}

\author{
Sanjeeb Kumar Patro, D. Sasmal*, Papiya Mitra Mazumder, Ashok Pattnaik, \\ Padmacharan Behera, Arpita Ghosh \\ Department of Pharmaceutical Science \& Technology, Birla Institute Technology, Mesra, Ranchi-835215
}

\begin{abstract}
Ethno pharmacological relevance: Canthium coromandelicum (Burm.f.) Alston (Syn. C. parviflorum) of Family: Rubiaceae is a bushy thorny suffruticose herb, native of India found mainly in coromandelicum region. This plant has been used traditionally in East Asia particularly in India to treat various diseases including GI disorders like gastric ulcer and diarrhea.
\end{abstract}

Aim of the study: The aim of the present study is to evaluate the gastroprotective activity Canthium coromandelicum (Burm.f.) Alston.

Materials and methods: Ethyl acetate fraction of methanolic extract of leaves of Canthium coromandelicum (EA-MECC) was carried out after successive hot extraction processes. Gastroprotective activity was performed by using the protocol of two ulcer induced models namely, pylorus ligation + Aspirin (NSAIDs) and Ethanol/HCl induced models. The macroscopic analysis of stomach, evaluation of gastric content parameters along with invivo antioxidant assays like, malanodialdehyde (MDA), Catalase (CAT) and Superoxide dismutase (SOD) enzyme assays in various groups of stomach tissue homogenates were done. Histopathological study was also carried out in both the ulcerated models.

Results: The results indicate that the gastroprotective effect of EA-MECC in both the ulcerated model was significantly $(p<0.001)$ protected in dose depended manner. Furthermore, EA-MECC also significantly $(p<0.001)$ reduced the various biochemical parameters of gastric contents like volume, total acid, free acid pepsin and increased $\mathrm{pH}$ along with good invivo antioxidant activities in all assay tasted animals compared to control in the doses of 100 and $200 \mathrm{mg} / \mathrm{kg} \mathrm{b.w}$. No sign of toxicity was observed in acute toxicity study. Histopathological examination of stomach tissues also showed better protection of the gastric mucosa in a dose dependent manner as indicated by reduction or absence of submucosal oedema, hemorrhagic erosions, lesions and infiltration of leucocytes.

Conclusion: The present study revealed that the EA-MECC has an antiulcerogenic activity, as demonstrated by the significant inhibition of the formation of ulcers in various models may be due to the presence of flavonoids, saponins, alkaloids, glycosides, tannins, terpenoids and phenols. This study scientifically justifies the traditional claim of antiulcer property.

Key words: Canthium coromandelicum, Gastroprotective, gastric ulcer, pylorus ligation+ aspirin induced gastric ulcer; Ethanol/HCl induced gastric ulcer.

\section{Introduction}

Two common types of ulcer located in gastrointestinal tract such as, peptic ulcer (stomach) and ulcerative colitis (lower part of intestine). Peptic ulcer or gastric ulcer is one of the major chronic human disease affecting millions of the people ie, nearly about $8-10 \%$ of population around the globe ${ }^{[1]}$. It is a common chronic illness found among working adults. Each year about 350,000 new cases were diagnosed; out of which 100,000 patients were hospitalized and at least about 3000 people died there of ${ }^{[2]}$. Pathophysiology of gastric ulcer has not been completely elucidated, but it developed when there was an imbalance between the 'aggressive' and 'protective' features at the luminal surface of the epithelial cells. Features like aggressive factors include Helicobacter pylori, $\mathrm{HCl}$, pepsins, NSAIDs (Nonsteroidal anti-inflammatory drugs), bile acids, ischemia, hypoxia, smoking and alcohol. While protective features include factors like bicarbonate, mucus layer, mucosal blood flow, PGs and other growth factors ${ }^{[3]}$. As per NIH (National Institute of Health) report in 1994, H. pylori are the major causative microbial organism for development of peptic ulcer ${ }^{[4]}$. In most of the countries people were habituated with alcoholic beverages. Scientifically alcohol is a necrotizing agent and its excessive use results sever gastritis with adhering symptoms like mucous membrane edema, sub epithelial hemorrhages, cell exfoliation and inflammatory cells infiltration ${ }^{[5]}$.

Several classes of pharmacological agents were reported to be effective in the treatment and prevention of the acid peptic ulcer disorders. These include: antacids, antisecretary drugs (acid suppressive agents) which 
include proton pump $\mathrm{H}^{+} / \mathrm{K}^{+}$-ATPase inhibitors (Omeprazole, Pentaprazole, Rabiprazole etc,), $\mathrm{H}_{2}$ - receptor antagonists (Ranitidine and Famotidine) and anticholinergic $\left(\mathrm{M}_{1}\right)$ (pirnzepine), cytoprotective agents (sucralfate and prostaglandin analogs, misoprostol), antimicrobials for eradication of $\mathrm{H}$. pylori (amoxicillin, clarithromycin) and Triple therapy (Triple therapy consisting of a proton pump inhibitor like Omeprazole and the antibiotics Clarithromycin and Amoxicillin/Metronidazole per week) ${ }^{[6]}$. However, these above marketed drugs on concomitant use are expensive and cause various adverse effects like hypersensitivity, gyanocomestia, impotency, arrhythmia and hematopoietic changes, thereby limiting their usefulness to human systems ${ }^{[7]}$.

In this regard, an exploration search has been launched to identify naturally occurring antiulcer drugs to replace the currently used synthetic drugs of doubtful efficacy and safety. A large number of medicinal plants with their secoundary metabolites ie., bioactive molecules with potential antiulcer activity have been reported in scientific literatures ${ }^{[8]}$. Amongst such secoundary metabolites the alkaloids, flavonoids, saponins, triterpenoids and tannins were found to be important for gastro protective function ${ }^{[1]}$.

Canthium coromandelicum under (Burm.f) Alston (Syn. C. parviflorum) belonging to Family: Rubiaceae is a bushy thorny suffruticose herb, native of India found mainly in coast of coromandelicum region of India. This plant has been used traditionally in East Asia particularly in India to treat various diseases like Intestinal worms in children, antioxidant and diuretics, Scabies and the ring worm infections, leucorrhoea, headache, fever, diabetes, snake bite, Indigestion, nausea, dysuria, impotence, GI disorders like gastric ulcer, diarrhea and constipation ${ }^{[9-13]}$.

A few preclinical pharmacological evaluations have been carried out in various parts of this plant revealed from the literature through scientific investigation. Canthium coromandelicum leaves have been reported to exhibit significant antimicrobial and anti - HIV activity ${ }^{[14]}$, hypocholesterolaemic activity ${ }^{[15]}$, oral hypoglycemic activity ${ }^{[16]}$, Wound healing and diuretic activities ${ }^{[11]}$, antioxidant properties ${ }^{[17]}$, antibacterial activity $^{[18]}$, Invitro and invivo anticancer activity on DLA and Hela cell lines ${ }^{[19]}$, antioxidant activity in Alloxan induced diabetic rats ${ }^{[20]}$. As there is lack of scientific validation against such published report on GI disorder of this plant, the present investigation was undertaken to evaluate its antiulcer activity in various ulcer induced models and also to evaluate the different biochemical parameters of gastric fluid and stomach tissue homogenate.

\subsection{Collection and authentification of Plant materials}

\section{Materials And Methods}

Leaves of Canthium coromandelicum were collected from the campus of College of Pharmaceutical sciences (CPS) Mohuda village, Brahmapur, Ganjam, Odisha during the month of June-August 2012. The plant materials had been identified by Prof. S. K. Dash, Taxonomist, Department of Biosciences, CPS, Brahmapur, Ganjam, Odisha and authenticated further too from taxonomy department of Botanical Survey of India (BSI), Kolkata. The voucher specimen (CNH/76/2012/Tech.II/899) was retained in the Department of Pharm. Science $\&$ Technology, BIT- Mesra, Ranchi, Jharkhand (India) for future reference.

\subsection{Preparation of extract}

The leaves were washed to clean the adhered debris and allowed to shad dried room temperature keeping away from sunlight. The dried leaves were powdered with the help of tissue blender. About $1 \mathrm{~kg}$ of air dried powder was successively extracted through hot extraction processes using Soxhlet apparatus with 6Liters of solvents with chronologically increasing order of polarity index viz., petroleum ether (40-60 grade), chloroform and methanol for 72 hours or till colourless at a temperature not exceeding the boiling point of the respective solvent. The crude extracts were filtered and the filtrates were concentrated under vacuum at $50^{\circ} \mathrm{C}$ by using rotary evaporator. All the extracts were stored in Vacuum desiccators for further use.

\subsection{Preliminary phytochemical studies}

The different leaf extracts of C. coromandelicum were tested for the major class of secondary metabolites like steroids, alkaloids, glycosides, saponins, flavonoids, phenolic compounds, tannins, triterpenoids, carbohydrates, proteins and fats etc. Phytochemical screening of the extracts was carried out according to the standard methods described by Harborne, (1998) with some modifications ${ }^{[21]}$.

\subsection{Invitro antioxidant activities of fractionations}

The extract which contained highest amount of Phytochemical constituents was subjected to further fractionation by separating funnel method using different solvents like water, $\mathrm{n}$ - Butanol, and ethyl acetate was carried out according to the standard methods described by Mukherjee, (2000) ${ }^{[22]}$. Various invitro antioxidant activities were performed in all the fractions according to the methods described by Shen Q et al., (2010); Hallowell (1989) \& Arti RV et al., (2010) $)^{[23-25]}$. 


\subsection{Animals}

Albino rats of either sex (180-200 g) and mice of either sex (25-30 g) were procured from the animal house of Department of Pharmaceutical Science \& Technology, BIT, Mesra, Ranchi, Jharkhand (India). All animals were housed in standard cages and allowed to acclimatize for 1 week before the commencement of the experimental study. Standard commercial food and water were provided ad libitium to the animals. Dwelling conditions were maintained at $25 \pm 2^{\circ} \mathrm{C}$ at $12 \mathrm{~h}$ day/ night cycles. This study was given ethical clearance by the Institutional Animal Ethics committee, Department of Pharmaceutical Science \& Technology, Birla Institute of Technology, Mesra, Ranchi, Jharkhand (India). Approval No: BIT/PH/IAEC/23/2013 in September 2013 under CPCSEA guidelines.

\subsection{Pharmacological evaluations}

\subsubsection{Acute toxicity study $\left(L D_{50}\right)$}

The acute toxicity was performed in albino mice, maintained under standard conditions. Overnight fasted animals were used as per the protocol. Fixed dose (OECD Guideline no. 423, Annexure 2d) method of CPCSEA was adopted for toxicity studies. The tested extract was administered orally. The sign of mortality was observed at $2000 \mathrm{mg} / \mathrm{kg}$ in all the cases (OECD, 1997). Common side effects such as, mild diarrhea, loss of weight and depression of treated groups of animals were recorded within the 7 days of the observation period ${ }^{[26]}$.

\subsubsection{In-vivo antiulcer activity studies}

\subsubsection{Pyloric ligation + NSAID induced ulcer model}

This test was performed following treatise of Maheswari et al., (2007) ${ }^{[27]}$. Overnight fasted rats were randomly divided into four groups of six animals each. Group1 (control) was given $1 \mathrm{ml}$ of vehicle (dist. water), Group 2 (standard) was treated with Ranitidine ( $30 \mathrm{mg} / \mathrm{kg}$ ) and Group 3 and 4 (test groups) were received 100 and $200 \mathrm{mg} / \mathrm{kg}$ b.w. of EA-MECC, consecutively for 5 days. All treatments were done through oral route. On 5th day, One hour after treatment, all animals were administered aspirin $(100 \mathrm{mg} / \mathrm{kg} \mathrm{b.w.})$ to induce gastric ulcer. One hour after aspirin treatment all the animals were carried out pylorus ligation according to the method adopted by Shay et al., (1945) with slight modification ${ }^{[28]}$. After 4 hours of pylorus ligation, all animals were sacrificed under anesthesia; the stomachs were removed, and opened along with the greater curvature. Stomachs were gently rinsed with water to remove gastric contents and blood before scanning. The obtained images were analyzed aftermath.

\subsubsection{HCl/Ethanol induced ulcer model}

This experimental model was performed according to the method of Nwafor et al., (2005) ${ }^{[29]}$. Overnight fasted rats were randomly divided into four groups of six animals each. To the first Group (control) 1 $\mathrm{ml}$ of vehicle (distilled water) was administered, and the second group (standard) was treated with Omeprazole $(30 \mathrm{mg} / \mathrm{kg}$ ). The remaining two groups ie., Group 3 and 4 were received with 100 and $200 \mathrm{mg} / \mathrm{kg}$ b.w. of EAMECC, consecutively for 5 days. All treatments were done through oral route. On 5th day, One hour after treatment, all rats administered orally $1 \mathrm{ml}$ of $0.3 \mathrm{M}$ solution of HCL in $60 \%(\mathrm{v} / \mathrm{v})$ ethanol according to the method of Mizui and Doteuchi (1983) to induce gastric ulcer ${ }^{[30]}$. One hour later, all the animals were sacrificed under anesthesia; the stomachs were removed, and opened along with the greater curvature. Stomachs were gently rinsed with water to remove gastric contents and blood before scanning. The obtained images were analyzed aftermath.

\subsubsection{Determination of volume, $\mathrm{pH}$, total acid and free acid of gastric juice:}

\subsubsection{1. $\mathrm{pH}$}

$1 \mathrm{ml}$ aliquot of gastric juice was diluted with $1 \mathrm{ml}$ of distilled water and $\mathrm{pH}$ of the solution was measured using $\mathrm{pH}$ meter ${ }^{[31]}$.

\subsubsection{Determination of total acidity:}

$1 \mathrm{ml}$ aliquot of gastric juice was diluted with $1 \mathrm{ml}$ of distilled water was taken in a $50 \mathrm{ml}$ conical flask and 2-3 drops of phenolphthalein indicator was added to it and then titrated with $0.01 \mathrm{~N} \mathrm{NaOH}$ until a permanent pink colour was observed ${ }^{[31]}$. The volume of $\mathrm{NaOH}$ consumed was noted. The total acidity is expressed as $\mathrm{mEq} / \mathrm{L}$ using the following equation:

$$
\text { Acidity }=(\text { vol. of } \mathrm{NaOH} \times \mathrm{N} \times 100) / 0.1 \mathrm{mEq} / \mathrm{L} / 100 \mathrm{gm}
$$

\subsubsection{Determination of free acid:}


Instead of phenolphthalein indicator, the Topfer's reagent $(0.5 \%$ dimethylaminoazobenzene in $95 \%$ alcohol) was used. Aliquot of gastric juice was titrated with previously standardized $0.01 \mathrm{~N} \mathrm{NaOH}$ consumed was noted the free acidity was calculated by the same formula for the determination of total acidity ${ }^{[31]}$.

Acidity $=($ vol. of $\mathrm{NaOH} \times \mathrm{N} \times 100) / 0.1 \mathrm{mEq} / \mathrm{L} / 100 \mathrm{gm}$

\subsubsection{Invivo antioxidant assays \& Biochemical estimations:}

\subsubsection{Determination of pepsin in gastric content}

Determination of pepsin in gastric content is carried out according to the method of Srivastav et al., (2010) ${ }^{[32]}$. Aliquots of $20 \mu \mathrm{l}$ of gastric content were incubated with $500 \mu \mathrm{l}$ of bovine serum albumin solution $(5 \mathrm{mg} / \mathrm{ml}$ in $0.06 \mathrm{~N} \mathrm{HCl})$ at $37^{\circ}$ for 10 minutes. The reaction was stopped with $200 \mu 1$ of $10 \%$ trichloro acetic acid (TCA) and samples were centrifuged at $1500 \mathrm{rpm}$ for 20 minutes. The supernatant was alkalinized with $2.5 \mathrm{ml}$ of $0.55 \mathrm{M}$ sodium carbonate and $400 \mu \mathrm{l}$ of $1.0 \mathrm{~N}$ Folin's reagent was added to the tubes, which were incubated for 30 minutes at room temperature. Absorbance was determined at $660 \mathrm{~nm}$. Finally, the concentration of pepsin was determined by standard curve.

\subsubsection{Assay of malanodialdehyde (MDA) in stomach tissue homogenate}

Preparation of homogenate: stomach tissues were homogenized with 10 times $(\mathrm{w} / \mathrm{v})$ ice-cold $0.1 \mathrm{M}$ phosphate buffer $\mathrm{pH}$ 7.4. Aliquots of homogenates from rat stomach tissue were used to determine lipid peroxidation.

Lipid peroxidation was estimated in terms of thiobarbituric acid reactive species (TBARS), using malanodialdehyde (MDA) as standard. Thus $1 \mathrm{ml}$ of homogenized gastric tissue in $2 \mathrm{ml}$ of normal saline was mixed with $20 \%$ TCA and centrifuged at $2000 \mathrm{rpm}$ for 20 minutes. To $2 \mathrm{ml}$ of protein-free supernatant, $1 \mathrm{ml}$ of fresh TBA $(0.67 \%)$ reagent was added, mixed thoroughly and heated at $95^{\circ} \mathrm{C}$ for 1 hour, in a water-bath. The suspension was than cooled at room temperature, centrifuged at $2000 \mathrm{rpm}$ for 10 minutes, and the pink colour supernatant was taken for spectroscopic measurement at $532 \mathrm{~nm}$ for the assay of MDA. Lipid peroxide is expressed in terms of $\mathrm{nM}$ of $\mathrm{MDA} / \mathrm{mg}$ of gastric tissue. As $99 \%$ TBARS are malanodialdehyde (MDA), so TBARS concentrations of the samples were calculated using the extinction co-efficient of MDA, which is $1.56 * 105 \mathrm{M} / \mathrm{cm}^{[33]}$.

\subsubsection{Assay of Catalase (CAT)}

This assay was carried out according to the method of Arun et al., (2008) ${ }^{[34]}$. The enzyme Catalase (CAT), catalyzes the conversion of $\mathrm{H}_{2} \mathrm{O}_{2}$ into water. The CAT activity was measured using the method of Chance and Maehly, (1952) with some modification. The CAT reaction solution $3 \mathrm{ml}$ contained; $100 \mathrm{mM}$ phosphate buffer ( $\mathrm{pH}$ 7.4), $30 \mathrm{mM} \mathrm{H}_{2} \mathrm{O}_{2}$ and $0.1 \mathrm{ml}$ of enzyme extract. The reaction was initiated by adding the enzyme extract. Change in absorbance of the reaction solutions at $240 \mathrm{~nm}$ were noted after every 30 seconds. One unit CAT activity was defined as the amount of enzyme required to decompose 1 micromole of $\mathrm{H}_{2} \mathrm{O}_{2} / \mathrm{min}$ calculated by using the molar extinction co-efficient $0.0394 \mathrm{mM} / \mathrm{min}$ for $\mathrm{H}_{2} \mathrm{O}_{2}$.

\subsubsection{Assay of Superoxide dismutase (SOD)}

Superoxide dismutase was estimated by using the method described by Misra et al., (1972) ${ }^{[35]} .0 .5 \mathrm{ml}$ of tissue homogenate was diluted with $0.5 \mathrm{ml}$ of distilled water, to which $0.25 \mathrm{ml}$ of ice cold ethanol and $0.25 \mathrm{ml}$ of ice cold chloroform was added. The mixture was mixed well using cyclomixer for 5 minutes and centrifuged at $2500 \mathrm{rpm} .1 .5 \mathrm{ml}$ of carbonate buffer and $0.5 \mathrm{ml}$ of EDTA solution were added with $0.5 \mathrm{ml}$ of supernatant. The reaction was initiated by the addition of $0.4 \mathrm{ml}$ of epinephrine and the change in OD/minute was measured at $480 \mathrm{~nm}$ against reagent blank. SOD activity was expressed as units/ $\mathrm{mg}$ of protein. Change in optical density per minute at 50\% inhibition of epinephrine to adrenochrome transition by the enzyme is taken as the enzyme unit. Calibration curve was prepared by using standard Superoxide dismutase.

\subsubsection{Histopathological examination}

Histopathological examination was carried out according to the method described by Pattanayak et al., (2008) ${ }^{[36]}$. After collection of gastric content and measuring the ulcer area, the stomach tissues of all groups of animals were washed in normal saline, cut into the desired size and fixed in neutral buffered formalin $(10 \%$ $\mathrm{HCHO}$ in phosphate buffer saline) for $24 \mathrm{hrs}$. After fixation, tissues were dehydrated and embedded in paraffin as per standard procedure. Section of tissues were made in microtome of $5 \mu \mathrm{m}$ in thickness and mounted in slides. The mounted slides were stained with Hematoxylin and Eosin for photographic observation.

\subsection{Statistical analysis}

The experimental data were expressed as mean \pm standard error of the mean (SEM). Statistical analysis of all the data were evaluated according to one-way analysis of variance (ANOVA) using statistical software 
Graph pad prism version 6. The significance of difference was evaluated using one way ANOVA followed by Dunnett's multiple comparison tests. Probability values of ${ }^{* * * *} \mathrm{p}<0.0001,{ }^{* * *} \mathrm{p}<0.001,{ }^{* *} \mathrm{p}<0.01,{ }^{*} \mathrm{p}<0.05$ were compared with control.

\section{II. Results}

Preliminary phytochemical screening of different metabolites (steroids, alkaloids, phenolic groups, tannins, coumarins and anthraquinones etc) were tested in four different extracts of $\mathrm{C}$. coromandelicum. The methanolic extract revealed the presence of more phytoconstituents than other extracts (data not shown). Based on the active principles, the crude methanolic extract of $\mathrm{C}$. coromandelicum was fractionated with different solvents like ethyl acetate, $\mathrm{n}$-Butanol and water. All the fractions were subjected for in vitro antioxidant studies, ethyl acetate fraction was found to be more potent in-vitro antioxidant activity with $\mathrm{IC}_{50}$ value than other fractions (Table 1).

\subsection{Acute toxicity study}

In acute toxicity study, the sample did not exhibit mortality at the dose of $2000 \mathrm{mg} / \mathrm{kg}$. Therefore 2000 $\mathrm{mg} / \mathrm{kg}$ dose was chosen as LD50 (lethal dose 50) in accordance with Globally Harmonized Classification System (GHS) category 5 (safe dose), as per OECD guideline 423 (Annexure 2d). Common side effects such as, loss of weight and depression of treated groups of animals were not recorded within the 7 days of the treatment period. Thus, in present study, only $100 \mathrm{mg} / \mathrm{kg}$ and $200 \mathrm{mg} / \mathrm{kg}$ b.w. dose were selected for in-vivo studies.

\subsection{Gastroprotective studies}

\subsubsection{Pylorus ligation + Aspirin (NSAID) induced gastric ulcer}

Gastric lesion measurements (red coloration, spot ulcers, hemorrhagic streaks and perforations in glandular gastric mucosa) of oral administration of aspirin $(100 \mathrm{mg} / \mathrm{kg})$ induced pylorus ligated animals showed that EA-MECC at the dose of 100 and $200 \mathrm{mg} / \mathrm{kg}$ significantly reduced $(\mathrm{p}<0.001)$ the ulcer score in dose depended manner as compared with control. The ulcer inhibition was found $65.57 \%$ and $81 \%$ respectively, while ranitidine showed $85.71 \%$ protection in comparison to the control (Table 2).

\subsubsection{HCV/Ethanol induced gastric ulcer}

The EA-MECC provided significantly $(\mathrm{p}<0.001)$ protection against gastric lesions induced by acidified ethanol. The results showed that the test groups of animals treated orally with doses of 100 and $200 \mathrm{mg} / \mathrm{kg}$ presented a percentage inhibition of $69.22 \%$ and $76.62 \%$ respectively, while Omeprazole presented a percentage inhibition of $85.18 \%$ as compared to the control (Table 3).

\subsubsection{Evaluation of gastric juice parameters in Pylorus ligation + Aspirin (NSAID) induced gastric ulcer}

The effect of EA-MECC up on acid secretion collected after 5 hours of pylorus ligature in animals were shown in Table 3. Oral administration in both the doses significantly reduced the volume of gastric acid secretion by $36 \%(\mathrm{p}<0.01)$ and $49.81 \%(\mathrm{p}<0.001)$ respectively. As for the $\mathrm{pH}$ of gastric juice is concerned, both the doses showed significantly $(\mathrm{p}<0.01)$ increase in $\mathrm{pH}$ value of $59.34 \%$ and $70.57 \%$ as compared to the control. Meanwhile, the total acidity was significantly reduced in 100 and $200 \mathrm{mg} / \mathrm{kg}$ of EA-MECC about $44.59 \%(\mathrm{p}<0.001)$ and $70.48 \%(\mathrm{p}<0.01)$ respectively. Similarly, free acid output also significantly decreased in the dose of $200 \mathrm{mg} / \mathrm{kg}$ about $58.7 \%(\mathrm{p}<0.01)$ where as insignificant in $100 \mathrm{mg} / \mathrm{kg}$ as compared with control group. Ranitidine $(30 \mathrm{mg} / \mathrm{kg})$ caused a reduction in the volume of secretion by $50 \%(\mathrm{p}<0.0001)$, increased $\mathrm{pH}$ by about $73.57 \%(\mathrm{p}<0.0001)$ and significantly $(\mathrm{p}<0.001)$ decreased the total acidity $\&$ free acidity of gastric juice by about $72.12 \%$ and $69.55 \%$ respectively when compared to control.

The secretion of pepsin in to gastric juice was also decreased in treatment groups in dose depended manner of EA-MECC. The dose of 100 and $200 \mathrm{mg} / \mathrm{kg}$ b.w. reduced the pepsin content about $32.21 \%(\mathrm{p}<0.01)$ and $53.91 \%(\mathrm{p}<0.0001)$ respectively as compared with control. Ranitidine $(30 \mathrm{mg} / \mathrm{kg})$ caused a reduction in the pepsin secretion by $64.34 \%(p<0.0001)$. All the above parameters were depicted in Table 2 .

\subsubsection{Evaluation of gastric juice parameters in HCl/Ethanol induced gastric ulcer}

The effect of EA-MECC up on acid secretion collected after 5 hours of $\mathrm{HCl} /$ Ethanol induced gastric ulcer in animals were shown in Table 3. Oral administration in both the doses reduced the volume of gastric acid secretion by $40.19 \%(\mathrm{p}<0.05)$ and $42.18 \%(\mathrm{p}<0.01)$ respectively. As for the $\mathrm{pH}$ of gastric juice is concerned, both the doses showed significantly $(\mathrm{p}<0.001)$ increase in $\mathrm{pH}$ value of $45.69 \%$ and $60.89 \%$ as compared to the control group. Meanwhile, the total acidity was reduced in 100 and $200 \mathrm{mg} / \mathrm{kg}$ b.w. of EA-MECC about $55.36 \%$ $(p<0.001)$ and $65.08 \%(p<0.0001)$ respectively. Similarly, free acid output also decreased in the dose of 100 and $200 \mathrm{mg} / \mathrm{kg}$ about $41.19 \%(\mathrm{p}<0.001)$ and $64.83 \%(\mathrm{p}<0.0001)$ respectively, as compared to control. Standard drug Ranitidine $(30 \mathrm{mg} / \mathrm{kg})$ caused a reduction in the volume of secretion by $23.57 \%(\mathrm{p}<0.05)$, increased $\mathrm{pH}$ of about 
69.44\% $(\mathrm{p}<0.001)$ and significantly $(\mathrm{p}<0.0001)$ decreased the total acidity \& free acidity of gastric juice about $77.44 \%$ and $71.14 \%$ respectively when compared to control group.

The secretion of pepsin in to gastric juice was also significantly $(\mathrm{p}<0.0001)$ decreased in treatment groups in dose depended manner of EA-MECC. Both the doses reduced the pepsin content about $41.01 \%$ and $71.06 \%$ respectively as compared with control. All the above parameters were depicted in Table 3 .

\subsubsection{Evaluation of invivo antioxidant assays \\ 3.3.5.1. Evaluation MDA levels}

The level of MDA in animals treated with EA-MECC and standard drug ranitidine after the ulcer induction by Pylorus ligation + Aspirin (NSAIDs) can be seen in Fig 1. The treatment of rats with 100 and 200 $\mathrm{mg} / \mathrm{kg}$ b.w. of EA-MECC caused intense reductions of $38.76 \%(\mathrm{p}<0.05)$ and $53.66 \%(\mathrm{p}<0.01)$ respectively as compared to the control. The standard drug ranitidine $(30 \mathrm{mg} / \mathrm{kg}$ ) significantly $(\mathrm{p}<0.001)$ reduced to $74.31 \%$ in the level of MDA.

Similarly, the level of MDA in animals treated with EA-MECC and standard drug Omeprazole after the ulcer induction by acidified ethanol (HCl/Ethanol) can be seen in Fig 2. The treatment of animals with 100 and $200 \mathrm{mg} / \mathrm{kg}$ b.w. of EA-MECC significantly $(\mathrm{p}<0.001)$ reduced to 46.28 and $53.66 \%$ respectively in the level of MDA as compared to the control. The standard drug Omeprazole $(30 \mathrm{mg} / \mathrm{kg})$ produced a significant reduction $(81.91 \%)$ in the level of MDA $(p<0.0001)$.

\subsubsection{Evaluation CAT levels}

The level of CAT (Catalase) in animals treated with EA-MECC and standard drug ranitidine after the ulcer induction by Pylorus ligation + Aspirin (NSAIDs) can be seen in Fig 3. The treatment of animals with 100 and $200 \mathrm{mg} / \mathrm{kg}$ b.w. of EA-MECC caused significant increase level of $54.2 \%(p<0.01)$ and $84.18 \%(p<0.01)$ as compared to the control. The standard drug ranitidine $(30 \mathrm{mg} / \mathrm{kg})$ produced a significantly $(p<0.01)$ increase in $91.19 \%$ in the level of CAT.

Similarly, the level of CAT in animals treated with EA-MECC and standard drug Omeprazole after the ulcer induction by acidified ethanol ( $\mathrm{HCl} /$ Ethanol) can be seen in Fig 4 . The treatment of animals with 100 and $200 \mathrm{mg} / \mathrm{kg}$ b.w. of EA-MECC caused intense increases in $57.91 \%(p<0.01)$ and $79.93 \%(p<0.001)$ respectively in the level of CAT as compared to the control. The standard drug Omeprazole $(30 \mathrm{mg} / \mathrm{kg})$ produced a significant increase $84.02 \%$ in the level of CAT $(p<0.0001)$.

\subsubsection{Evaluation SOD levels}

The level of SOD in animals treated with EA-MECC and standard drug ranitidine after the ulcer induction by Pylorus ligation + Aspirin (NSAID) can be seen in Fig 5. The treatment of animals with 100 and $200 \mathrm{mg} / \mathrm{kg}$ of EA-MECC caused significant increase level of $50.41 \%(p<0.01)$ and $73.27 \%(p<0.001)$ as compared to the control group. The standard drug ranitidine $(30 \mathrm{mg} / \mathrm{kg}$ ) produced a significant increase $81.07 \%$ in the level of SOD $(p<0.001)$.

Similarly, the level of SOD in animals treated with EA-MECC and standard drug Omeprazole after the ulcer induction by acidified ethanol $(\mathrm{HCl} / \mathrm{Ethanol})$ can be seen in Fig 6 . The treatment of animals with 100 and $200 \mathrm{mg} / \mathrm{kg}$ b.w. of EA-MECC significantly $(p<0.001)$ increase in $56.32 \%$ and $77.45 \%$ respectively as compared to the control group. The standard drug Omeprazole $(30 \mathrm{mg} / \mathrm{kg})$ produced a significant increase $78.64 \%$ in the level of SOD $(p<0.001)$.

\section{3. 6. Histopathological examination}

Histological observation of ulcer induced stomach tissue pretreated only with $\mathrm{H}_{2} \mathrm{O}$ (control group) showed marked lesions and severe damage to the gastric mucosa, hemorrhagic erosion, oedema and leucocytes infiltration of the submucosal layer. On the other hand, stomach tissues of pylorus + aspirin induced rats pretreated with 100 and $200 \mathrm{mg} / \mathrm{kg}$ b.w. of EA-MECC showed mild lesions of the mucosa to almost normal mucosal architecture with very mild effects of hemorrhage and oedema. Overall, tissues that received pretreatment with EA-MECC showed better protection of the gastric mucosa in a dose dependent manner as indicated by reduction or absence of submucosal oedema and infiltration of leucocytes (Figure $7 \& 8$ ). For comparison purposes, stomach of Ranitidine and Omeprazole pretreated rats showed moderate protection of the mucosa with very mild hemorrhage and absence of oedema.

\section{Discussion}


In gastroprotective study, oral administration of EA-MECC showed a significant protection against ulcers induced by pylorus ligation + Aspirin (NSAIDs) and Ethanol/HCl in dose dependent manner as compared with control. Both the models were most widely used to study the effect of drugs in any sources on gastric acid and mucus secretion. NSAIDs causes inhibition of protective function of endogenous prostaglandins synthesis by blocking COX-1 enzyme and legating the pyloric end of stomach caused an increase in secretion as well as retention of $\mathrm{HCl}$ on mucosal layer of stomach leading to an auto digestion of gastric mucosa and breakdown of the gastric mucosal barrier ${ }^{[37]}$. Endogenous prostaglandins are responsible for regulation of secretion of mucus and bicarbonate, blood flow and proliferation of epithelial cells. Therefore, inhibition of prostaglandin synthesis by NSAIDs weakens the gastric mucosal system, leading to the formation of various lesions in the region of gastric epithelium $^{[38]}$. Similarly, Ethanol and $\mathrm{HCl}$ were necrotizing substances and its excessive use results in sever gastritis, characterized by edema of mucous membrane, hemorrhages of sub epithelial tissues, cell exfoliation and infiltration of inflammatory cells ${ }^{[5]}$. In addition, ethanol also causes generation of free radicals, increase lipid peroxidation, decreasing production of gastric mucus and inhibition of PGs ${ }^{[39]}$.

Generally Parietal cells or oxyntic cells of gastric glands secrets $\mathrm{HCl}$ that promotes proteolytic digestion of foodstuffs, absorption of iron and killing of pathogens ${ }^{[40]}$. The basolateral membrane of parietal cells located with specific receptors like acetylcholine, gastrin and histaminic $\left(\mathrm{H}_{2}\right)$ receptors. When these receptors occupied with acetylcholine, gastrin and histamine mediators causes stimulation of gastric acid that causes destruction of mucosal layer of stomach ${ }^{[41]}$. The regulation of $\mathrm{HCl}$ from parietal cells is a challenging task for pathogenesis of peptic ulcer. Hence, the inhibition of Gastric $\mathrm{HCl}$ is one of the important therapeutic targets for ulcer diseases ${ }^{[42]}$. In present study, our finding clearly understood that EA fraction of MECC inhibited the aggressive factor by significantly the volume of gastric acid secretion, total acid output, free acid output and pepsin in treated animals in comparison with control. This may be possible due to anti secretory properties of EA-MECC.

In gastric fluid parameters study, it was observed that there is increase in $\mathrm{pH}$ content in dose depended manner in EA-MECC treated animals. The increase in $\mathrm{pH}$ content is due to increase in the formation of gastric mucus, which plays an important role in gastric ulcer defense mechanism by forming continuous mucus like protective barrier coating over the mucosal membrane and maintains the $\mathrm{pH}$ of 6-7 in the acidic environment. Generally, weakening of mucosal defense can lead to severe injury in peptic ulcers except low acid secretion ${ }^{\text {[42] }}$. In biochemical assay evaluations, we found that the treatment of EA-MECC significantly reduced MDA level which is the end product of lipid peroxidation and this increased CAT and SOD enzyme level in both the gastric ulcer induced model in dose dependent manner in comparison to control group. Hence this study suggests that our EA-MECC shows a potent invivo antioxidant activity. The reduction of MDA level in both the ulcer model suggests that the EA-MECC has ability to prevent the formation of ROS and subsequent lipid peroxidation of the gastric mucosal tissues. During normal metabolism processes ROS also continuously produced and are constantly removed by an endogenous antioxidant defense mechanism. The imbalance in antioxidant systems may results in larger cellular changes in peroxidation of lipids, proteins and nucleic acids that can lead to cell death ${ }^{[43]}$. The expression of these antioxidant enzymes is stimulated by exposure to ROS ${ }^{[4]}$. Superoxide dismutase is an important defense enzyme, which catalyzes the dismutation of superoxide radicals ${ }^{[45]}$, and Catalase is a hemoprotein, which catalyzes the reduction of hydrogen peroxides $\left(\mathrm{H}_{2} \mathrm{O}_{2}\right)$ and protects tissues from highly reactive hydroxyl radicals ${ }^{[46]}$. The participation of antioxidant mechanism on the gastroprotective effects prevents the oxidative damage gastric mucosa by blocking lipid peroxidation and by significant increase in Catalase and Superoxide dismutase activity ${ }^{[47]}$.

In our preliminary phytochemical study, we found that the methanolic extract of leaves of C. coromandelicum contains number of phytoconstituents than other extracts. This extract revealed the presence of flavonoids, saponins, alkaloids, glycosides, tannins, terpenoids and phenols through strong positive tests. The result of EA-MECC showed more potent in vitro antioxidant properties for further selection of invivo biological activity. Flavonoids were reported various pharmacological properties like antioxidant ${ }^{[48]}$, antispasmodic ${ }^{[49]}$, antiulcer ${ }^{[50]}$, anti-secretory, anti-diarrheal ${ }^{[51]}$ activities in GI tract and anti-inflammatory properties ${ }^{[52]}$. As for mechanism of action is concerned, flavonoids are able to activate the mucosal defense system through stimulation of gastric mucus secretion and scavenge for reactive oxygen species and free radicals generated by necrotizing factors like ethanol and aspirin ${ }^{[53]}$. Further, they have also capacity to decrease ulcerogenic lesions by promoting the formation of gastric mucosa, inhibition of pepsinogen production and diminish acid mucosal secretion ${ }^{[50]}$. Like flavonoids, saponins were also exerting their protective activities in ulceration by the activation of mucus membrane protective factors ${ }^{[54]}$. They act mainly through antisecretary mechanism by inhibiting acid secretion, total acid output and lowered PH value of gastric juice ${ }^{[55]}$. Similarly, tannins are known to "tan" the outer layer of mucosa and it allows less permeable and strong resistant to chemical and mechanical injury or irritation ${ }^{[56]}$. Tan and Nyasse in 2000 reported most of the alkaloids possess prophylactic antiulcerogenic activity through enhancement of mucus production along with direct and indirect antioxidant activities ${ }^{[57]}$. In addition, terpenoids shows antiulcerogenic activity by increasing the production of mucus in 
stomach through different mechanisms like increase in PG content, improving mucosal blood flow and secretion of gastric bicarbonate and mucus accelerating ulcer healing ${ }^{[58]}$ along with reducing lipid peroxide level and increasing in the antioxidant enzymes such as superoxide dismutase (SOD) and Catalase (CAT) in the gastric mucosa ${ }^{[59]}$.

\section{Conclusion}

The present study revealed that the EA-MECC has an antiulcerogenic activity, as demonstrated by the significant inhibition of the formation of ulcers in various models may be due to the presence of flavonoids, saponins, alkaloids, glycosides, tannins, terpenoids and phenols. This study scientifically justifies the traditional claim of antiulcer property. This is for the first time reported the gastroprotective activity of this plant species. Hence, the ethno pharmacological use of leaf extract of C. coromandelicum, contributing to its pharmacological validation and suggesting that the preparation could be used for the development of new phytopharmaceuticals for the treatment of gastric ulcer.

\section{Acknowledgements}

The authors would like to acknowledge AICTE (QIP), Govt. of India for financial support, Botanical Survey of India, Kolkata for authentification of plant specimen \& Department of Pharmaceutical Science \& Technology, Birla Institute of Technology, Mesra, Ranchi, India for providing the research facilities to carry out the study.

\section{Declaration Of Interest}

The authors report no declarations of interest. The authors alone are responsible for the content and writing of the paper.

\section{References}

[1] klein-Junior, LC., Gandolfi, R.B.,Santin, J.R., Lemos M., Cechinel Filho, V., Andrade, S.F. Antiulcerogenic activity of extract, fractions, and some compounds obtained from Polygola cyparissias St Hillaire \& Moquin (Poligalaceae). Naunym-Schmiedberg's Archives of Pharmacology 381, 2010, 121-126.

[2] Crawford, A.S., White, J.G. Celecoxib-induced upper gastrointestinal hemorrhage and ulceration. Southern Medical Journal, 95, 2002, 1444-1446.

[3] Harold, Kalant, Grant, Denis, M., Mitchel, Jane. Principles of Medical Pharmacology, Seventh ed. Elsevier Canada Ltd., 2007, p.557- 559 .

[4] National Institute of Health, NIH, 1994. Consensus Conference. Helicobacter pylori in peptic ulcer disease. Journal of the Am erican Medical Association 272, 2000, 65-69.

[5] Gulsandi, M. Effect of ethanol on gastric mucosa. Digestive Disease 5, 1987, 21-32.

[6] Waller, D.G., Renwick, A.G., Hillier, K. Medical Pharmacology and Therapeutics second ed. Elsevier Limited, 2005, 347-401.

[7] Santin, J.R., Lemos, M., Junior, L.C.K., Niero, R., Andrade, S.F. Antiulcer activity of Achyroline satureoides Lam. (Asteraceae). A folk medicinal plant in different experimental models. Journal of Ethnopharmacology 130, 2010, 334-339.

[8] Borelli, F., Izzo, A.A. The Plant kingdom as a source of anti-ulcer remedies. Phytother. Res. 2000, 14, 581-591.

[9] Anitha. B., Mohan V.R., Athiperumalsami. T, and Sudha. S.. Ethnomedicinal plants used by kanikkaras of Tirunilveli District, Tamilnadu, India to treat skin diseases. Ethnobotanical leaflets, 12, 2008, 171-180.

[10] Ayyanar. M., Sankarasivaraman K., and Ignacimuthu. S. Traditional Herbal Medicines used in the treatment of Diabetes among two major tribal groups in south Tamil Nadu, India. Ethnobotanical Leaflets, 12, 2008, 276-280.

[11] Mohideen. S., Ilavarasan. R., Hemalata S., Anitha, N., and Sasikala, E. Wound healing and diuretic activities of Canthium parviflorum Lam. Natural product sciences. 9 (2), 2003, 102-104.

[12] Suresh K, Kotaimuthu R, Norman TSJ, Kumuthakalavalli R, Simon SM. Ethnomedicinal study of medicinal plants used by malayali tribals in kolli hills of Tamil Nadu, India. International Journal of Research in Ayurveda \& Pharmacy , 2(2), 2011, 502-508.

[13] Sambandan K, Dhatchanamoorthy N. Studies on the Phyto diversity f a Sacred Grove and its Traditional Uses in Karaika, 2011.

[14] Santhosh Kumar Chinnaiyan, Mohon Raj Subramanian, S. Vinoth Kumar, Atul N. Chandu, Karthkeyan Devaigamani. "Antimicrobial and anti-HIV activity of extracts of Canthium coromandelicum (Burm.f.) Alston leaves." Journal of Pharmacy Research 6(26), 2013, 1-7.

[15] Bandara, WVRTDG, Sagarika Ekanayake, ER., Jansz and Balasubramanium, K. The hypocholesterolaemic effect of Canthium Coromandelicum leaf on Wistar rats. Vidyodaya J. of Sci. 14, 2009, 105-109.

[16] Rahal Widanagamage., Sagarika EkanayakeOral hypoglycemic effect of Canthium coromandelicum leaf extract on Wistar rats. Vidyodaya J. of Sci. 14, 2009, 53-57.

[17] Satish kumar. T., Sahanmugam. S., Palvannan. T., and Bharati Kumar V. M. Evaluations of antioxidant properties of Canthium parviflorum Lam leaves. Natural Product Radiances 7(2), 2008, 122-126.

[18] P.sathya pariva., J.M. Sasikumar., and G. Gowsigan.. Antibacterial activity of methanolic extract of Ruta chalapensis (L), Quercus infectoria (Oliver) and Canthium parviflorum (Lam) Anc Sci Life, 29(2), 2009, 28-31.

[19] Purushoth Prabhu.T., Panneerselvam, P., Selvakumari. S. I., Sivaraman. D. "Invitro and invivo anticancer activity of Ethanolic extract of Canthium Parviflorum Lam on DLA and Hela cell lines". Int. J. Drug Dev. \& Res 3(4), 2011, $280-285$.

[20] Purusoth prabhu T, Selva kumari S., clement Atlee W., vijayakumar R., Suresh R. Antioxident Activity of ethanolic extract of Canthium Parviflorum Lam. in Alloxan induced Rats. International Journal of Ayurvedic and Herbal Medicine 2(5), 2012, 766670 .

[21] Harborne, JB. Phytochemical Methods. a guide to modern techniques of plant analysis, 3rd Edn. Chapman and Hall, New York, 1998; pp. 1-150.

[22] Mukherjee PK. Quality Control Of Herbal Drugs: An approach to evaluation of botanicals. $4^{\text {th }}$ ed. Business Horizon;.230-300. 
[23] Shen Q, Zhang B, Xu R, Wang Y, Ding X, Li P. Antioxidant activity in vitro of the selenium-contained protein from the Seenriched Bifidobacterium animalis. Anaerobe 16(4), 2010, 380-386.

[24] Halliwell, B., Gutteridge, JMC. Free radicals, aging and diseases, in free radicals biology and medicine. Oxford: Oxford Univ ersity Press, 1989, 419-422.

[25] Arti RV, Vijayakumar M Rao ChV, Mathela CS. In vitro and in vivo antioxidant properties and DNA damage protective activity of green fruit of Ficus glomerata. Food chem. Toxicol. 48, 2010, 704-709.

[26] Prema Veeraghavan, expert consultant, Committee for the Purpose of Control and Supervision of Experiments on Animals (CPCSEA), Animal Welfare Division, Government of India (Guideline No. 423, Annexure-2d of OECD). $19^{\text {th }}$ September, 2001.

[27] Maheswari, M.U., Kumar, K.A., Rathidevi, R., Sivashanmugam, A.T., Subhadradevi, V., and Ravi T.K. Antiulcer and invitro antioxidant activities of Jasminum grandiflorum L. Journal of Ethnopharmacology, 110 (3), 2007, 464-470.

[28] Shay, J.P., Komarov, S.A., Fels, S., Meranze, D., Grunstein, M., Simpler, H. A simple method for the uniform production of gastric ulceration in the rat. Journal of Gastroenterology 5, 1945, 43-61.

[29] Nwafor, P.A., Jacks, T.W., Ekanem, A.U., Ching, F.P. Nigerian Journal of Natural Product and Medicine, 9, 2005, 66-70.

[30] Mizui and Doteuchi (1983)

[31] Dasputre, N.L., Naikwade N.S. Evaluation of antiulcer activity of methanolic extract of Abutilon indicum Linn leaves in experimental rats. International Journal of Pharmaceutical Sciences and Drug Research, 3(2), 2011, 97-100.

[32] Srivastava, V., Viswanathaswamy, A.H.M., Mohan, G. Determination of the antiulcer properties of sodium cromoglycate in pylorus ligated albino rats. Indian Journal of Pharmacology 42(3), 2010, 185-190.

[33] Dabnath, S., Kannadasan, M., Acharjee, A., Bhattacharjee, C., Kumar, S., Kumar, G.G. Antioxidant activities of the hydro alcoholic extract of Erythrina fusca Lour bark against the animal models of epilepsy. J. Chem. Pharm. Res. 2(5), 2010, $379-383$.

[34] Arun, M., Asha, VV. Gastroprotective effect of Dodonaca viscose on various experimental ulcer models. Bio Pharmacology, 2008, $460-465$.

[35] Misra, H. P., Fridovich, I. The role of Superoxide anion in the autoxidation of epinephrine and a simple assay for superoxide dismutase. J. Biol. Chem. 247, 1972, 3170-3175.

[36] Pattanayak, SP., Mazumder, PM. Histopathological approach to rat liver tissue. Protocol online: Your lab's reference book 1, 2008.

[37] Kumar, A., Singh, V., Chaudhary, A.K. Gastric antisecretary and antiulcer activities of Cedrus deodara (Roxb.) Loudin Wistar rats. J. Ethnopharmacol. 134, 2011, 294-297.

[38] Chand, F.K., Leung, W.K. Peptic ulcer disease. The Lancet, 2002, 360, 933-941.

[39] Abdel-Salam, O.M.E., Czimmer, J., Debreceni, A., Szolcsanyi, J., Mozsik, G.. Gastric mucosal integrity: gastric mucosal blood flow and microcirculation. An overview. Journal of Physiology-Paris, 95, 2001,105-127.

[40] Rang, H.P., Dale, M.M., Ritter, J.M., Flower, R.J., Henderson, G. Rang and Dale's Pharmacology, $7^{\text {th }}$ ed. Churchill Livingstone, Edinburg, 2012.

[41] Oiry, C., Pannequin, J., Cornnier, A., Galleyrand, J.C., Martinez, J. L-365, 260 inhibits Invitro acid secretion by interacting with PKA pathway. Br. J. Pharmacol. 127, 1999, 259-267.

[42] Jain, K.S., Saha, A.K., Bariwal, J., Shelke, S.M., Kale, A.P., Jagtap, J.R., Bhosale, A.V. Recent advances in proton pump inhibitors and management of acid peptic disorders. Bioorg. Med. Chem. 15, 2007, 1181-1205.

[43] Kaharamam, A., Erkasap, N., Koken, T., Serteser, M., Aktepe, F., Erkasap, S. The antioxidant and antihistaminic properties of quercetin in ethanol induced gastric lesions. Toxicology 183, 2003, 133-142.

[44] Yu, B.P. Cellular defenses against damage from reactive oxygen species. Physiological Reviews, 74, 1994, $139-161$.

[45] McCord, J. M., Boyle, J. A., Day, E. D., Rizzolo, L. J. and Salin, M. L. Superoxide and Superoxide dismutases (Michelson, A. M., and Fridovich, I., eds), Academic press, New York., 1977, 129-138

[46] Chance, B., D.S. Green Stein and R.J.W. Roughton,. The mechanism of catalase action 1 -stedy state analysis, 1952.

[47] Carvalho, K.I.M., Fernandes, H.B., Machado, F.D.F., Oliveira, I.S., Oliveira, F.A., Nunes, P.H.M., lima, J.T., Almeida, J.R.D.S., Oliveira, R.C.M. Antiulcer activity of ethanolic extract of Encholirium spectabile Mart. ex Schult \& Schult f. (Bromeliaceae)in rodents. Biol. Res. 43 (4), 2010, 459-460.

[48] Ferreira, J.F., Luthria, D.L., Sasaki, T., Heyerick, A. Flavonoids from Artemisia annua L. as antioxidants and their potential synergism with artemisinin against malaria and cancer. Molecules. 15, 201, 3135-3170.

[49] Lima, J.T., Almeida, J.R.G.C., Barbosa-Filho, J.M., Assis, T.S., Silva, M.S., Dacunha, E.V.L., Braz-Filho, R., Silva, B.A.. Spasmolytic action of diplotropin, a furanoflavan from Diplotropis ferruginea Benth., involves calcium blockade in guinea-pig ileum. J. Chem. Sci. 60, 2005, 1093-1100.

[50] La Casa, C., Villegas, I., Alarcon del a Lastra, C., Motilava, V., Calero, M.J.M. Evidence for protective and antioxidant properties of rutin, a natural flavone, against ethanol induced gastric lesions. Journal of Ethnopharmacology, 71, 2000, 45-53.

[51] Di, Carlo, G., Autore, G., Izzo, A.A., Maiolino, P., Mascolo, N., Viola, P., Diurno, M.V., Capasso, F. Inhibition of intestinal motility and secretion by flavonoids in mice and rats: structure-activity relationships. J. pharm. Pharmacol. 45, 1993, 1054-1059.

[52] Sandhar, H.K., Kumar, B, Prasher, S, Tiwari, P., Salhan, M., Sharma, P. A review of Phytochemistry and Pharmacology of flavonoids. Int. Pharm. Sci. 1, 2011, 24-41.

[53] Abdelwahab, S.I., Mohan,S., Abdulla,M.A., Sukari, M.A., Abdul,A.B., Taha,M.M., Syam, S., Ahamad, S., Lee, K.H.. The methanolic extract of Boesenbergia rotunda (L.) and its major compound pinostrobin induces antiulcerogenic property invivo: possible involvement of indirect antioxidant action. J. Ethnopharmacol. 137, 2011, 963-970.

[54] Choudhary, M.K., Bodakhe, S.H., Gupta, S.K.. Assessment of antiulcer potential of Moringa oleifera root-bark extract in rats. J. Acupunct. Meridian Stud. . 6, 2013, 214-220.

[55] Lee, F.B., Kim, O.J., Kang, S.S., Jeong, C. Araloside A, an antiulcer constituent from the root bark of Aralia elata. Biol. Pharm. Bull. 28, 2005, 523-526.

[56] Asuzu, J.U., Onu, O.U. Antiulcer activity of the ethanolic extract of Combretum dolicopitalum root. Int. j. Crude Drug Res, 28, 1990, 27-32.

[57] Tan, P.V., Nyasee, B., Enow-Orock, Wafo, P., Forcha, E.A. Prophylactic and healing properties of a new antiulcer compound from Enantia chlorantha in rats. Phytomedicine, 7, 2000, 291-296.

[58] Ohta, Y., Kamiya, Y., Imai, Y., Arisawa, T., Nakano, H.. plaunotol prevents the prognosis of acute gastric mucosal lesion induced by compound 48/80, a mast cell degranulator, in rats. Pharmacol. 74, 2005b, 182-192.

[59] Rodriguez, J.A., Theoduloz, C., Yanez, T., Becerra, J., Schmeda-Hirchmann, G. Gastroprotective and ulcer healing effect of ferruginol in mice and rats: Assessment of its mechanism of action using Invitro models. Life Sci. 78, $2006,2503-2509$. 
Table- 1: Invitro antioxidant activity of fractionated methanolic extract of leaves of Canthium coromandelicum (Burm.f.) Alston

\begin{tabular}{|c|c|c|c|c|c|}
\hline \multirow{2}{*}{ Test } & \multicolumn{3}{|c|}{$\mathrm{IC}_{50}$ value $(\mu \mathrm{g} / \mathrm{ml})$} & \multicolumn{2}{c|}{$\%$ of inhibition } \\
\cline { 2 - 6 } & EA-MECC & BU-MECC & AQ-MECC & Ascorbic acid $(10 \mu \mathrm{g})$ & Quercetin $(10 \mu \mathrm{g})$ \\
\hline DPPH & 117.03 & 510.23 & $>1000$ & 92.13 & 83.71 \\
\hline OH radical & 241.80 & 795.38 & $>1000$ & & \\
\hline
\end{tabular}

Table-2: Effect of EA fraction of MECC on gastric ulceration induced by pylorus ligation+ aspirin (NSAID) in rats

\begin{tabular}{|c|c|c|c|c|c|c|c|}
\hline $\begin{array}{l}\text { Treatment } \\
\text { groups }\end{array}$ & $\begin{array}{c}\text { Volume of } \\
\text { gastric juice } \\
(\mathrm{ml} / 4 \mathrm{hr})\end{array}$ & $\mathrm{pH}$ & $\begin{array}{c}\text { Total acid } \\
\text { output } \\
(\mathrm{mEq} / \mathrm{L})\end{array}$ & $\begin{array}{c}\text { Free acid } \\
\text { output } \\
(\mathrm{mEq} / \mathrm{L})\end{array}$ & $\begin{array}{c}\text { Pepsin } \\
\text { activity } \\
(\mu \mathrm{g} / \mathrm{ml})\end{array}$ & $\begin{array}{c}\text { Ulcer } \\
\text { score }\end{array}$ & $\begin{array}{c}\% \text { of } \\
\text { ulcer } \\
\text { protection }\end{array}$ \\
\hline $\begin{array}{c}\text { Control } \\
\text { (vehicle }\end{array}$ & $5.5 \pm 0.18$ & $1.48 \pm 0.14$ & $101.07 \pm 4.06$ & $38.33 \pm 3.809$ & $5.758 \pm 0.14$ & $7 \pm 0.447$ & -- \\
$2 \mathrm{ml} / \mathrm{kg})$ & & & & & & & \\
\hline $\begin{array}{c}\text { Standard } \\
\text { Ranitidine } 30 \\
\mathrm{mg} / \mathrm{kg})\end{array}$ & $\begin{array}{c}2.75 \pm 0.11^{* * * *} \\
(50 \%)\end{array}$ & $\begin{array}{c}5.6 \pm 0.17^{* * * *} \\
(73.57 \%)\end{array}$ & $\begin{array}{c}28.17 \pm 2.97^{* * *} \\
(72.12 \%)\end{array}$ & $\begin{array}{c}11.67 \pm 1.49^{* * *} \\
(69.55 \%)\end{array}$ & $\begin{array}{c}2.053 \pm 0.14^{* * *} \\
(64.34 \%)\end{array}$ & $\begin{array}{c}1 \pm 0.22^{* * * *} \\
(85.71 \%)\end{array}$ & $\mathbf{8 5 . 7 1}$ \\
\hline $\begin{array}{c}\text { Test }-1 \\
\text { EAF of MECC } \\
(100 \mathrm{mg} / \mathrm{kg})\end{array}$ & $\begin{array}{c}3.51 \pm 0.21^{* *} \\
(36 \%)\end{array}$ & $\begin{array}{c}3.64 \pm 0.23^{* *} \\
(59.34 \%)\end{array}$ & $\begin{array}{c}56.0 \pm 2.80^{* * *} \\
(44.59 \%)\end{array}$ & $\begin{array}{c}26.33 \pm 1.25 \\
(31.3 \%)\end{array}$ & $\begin{array}{c}3.908 \pm 0.25^{* *} \\
(32.21 \%)\end{array}$ & $\begin{array}{c}2.41 \pm 0.271^{* *} \\
(65.57 \%)\end{array}$ & 65.57 \\
\hline $\begin{array}{c}\text { Test }-2 \\
\text { EAF of MECC } \\
(200 \mathrm{mg} / \mathrm{kg})\end{array}$ & $\begin{array}{c}2.76 \pm 0.1^{* * *} \\
(49.81 \%)\end{array}$ & $\begin{array}{c}5.03 \pm 0.55^{* *} \\
(70.57 \%)\end{array}$ & $\begin{array}{c}29.83 \pm 1.70^{* *} \\
(70.48 \%)\end{array}$ & $\begin{array}{c}15.83 \pm 0.87^{* *} \\
(58.7 \%)\end{array}$ & $\begin{array}{c}2.655 \pm 0.20^{* * * *} \\
(53.91 \%)\end{array}$ & $1.33 \pm 0.105^{* * *}$ & $\mathbf{8 1}$ \\
\hline
\end{tabular}

The results are expressed as mean \pm standard error of the mean $(\mathrm{SEM})$. Probability values of ${ }^{* * * *} \mathrm{p}<0.0001,{ }^{* * *}$ $\mathrm{p}<0.001,{ }^{* *} \mathrm{p}<0.01$ and ${ }^{*} \mathrm{p}<0.05$ were compared with control.

Table-3: Effect of EA fraction of MECC on gastric ulceration induced by $\mathrm{HCl} / \mathrm{ethanol}$ in rats

\begin{tabular}{|c|c|c|c|c|c|c|c|}
\hline Treatment groups & $\begin{array}{l}\text { Volume of } \\
\text { gastric juice } \\
(\mathrm{ml} / 4 \mathrm{hr})\end{array}$ & $\mathrm{pH}$ & $\begin{array}{c}\text { Total acid } \\
\text { output }(\mathrm{mEq} / \mathrm{L})\end{array}$ & $\begin{array}{l}\text { Free acid output } \\
\qquad(\mathrm{mEq} / \mathrm{L})\end{array}$ & $\begin{array}{l}\text { Pepsin } \\
\text { activity } \\
(\mu \mathrm{g} / \mathrm{ml})\end{array}$ & $\begin{array}{l}\text { Ulcer } \\
\text { score }\end{array}$ & $\begin{array}{l}\% \text { of ulcer } \\
\text { protection }\end{array}$ \\
\hline $\begin{array}{c}\text { Control } \\
\text { (vehicle } 2 \mathrm{ml} / \mathrm{kg} \text { ) }\end{array}$ & $4.03 \pm 0.302$ & $1.83 \pm 0.146$ & $101.2 \pm 3.859$ & $42.17 \pm 1.721$ & $6.29 \pm 0.865$ & $7.83 \pm 0.105$ & --- \\
\hline $\begin{array}{c}\text { Standard } \\
\text { (Omeprazol } 30 \\
\text { mg/kg) }\end{array}$ & $\begin{array}{l}3.08 \pm 0.16^{*} \\
(23.57 \%)\end{array}$ & $\begin{array}{c}5.99 \pm 0.17^{* *} \\
(69.44 \%) \\
\end{array}$ & $\begin{array}{c}22.83 \pm 1.79^{\text {***** }} \\
\quad(77.44 \%)\end{array}$ & $\begin{array}{c}12.17 \pm 0.09^{* * * *} \\
(71.14 \%)\end{array}$ & $\begin{array}{c}2.07 \pm 0.29^{* * * *} \\
(67.09 \%)\end{array}$ & $1.16 \pm 0.16^{* * * *}$ & 85.18 \\
\hline $\begin{array}{c}\text { Test }-1 \\
\text { EAF of MECC } \\
(100 \mathrm{mg} / \mathrm{kg})\end{array}$ & $\begin{array}{l}2.41 \pm 0.15^{*} \\
(40.19 \%)\end{array}$ & $\begin{array}{c}3.37 \pm 0.09^{* *} \\
* \\
(45.69 \%)\end{array}$ & $\begin{array}{l}45.17 \pm 2.49^{* * *} \\
\quad(55.36 \%)\end{array}$ & $\begin{array}{c}24.83 \pm 1.42^{* * *} \\
\quad(41.19 \%)\end{array}$ & $\begin{array}{l}3.71 \pm 0.08^{* * * *} \\
\quad(41.01 \%)\end{array}$ & $2.41 \pm 0.3^{* * * *}$ & 69.22 \\
\hline $\begin{array}{c}\text { Test }-2 \\
\text { EAF of MECC } \\
(200 \mathrm{mg} / \mathrm{kg})\end{array}$ & $\begin{array}{c}2.33 \pm 0.27^{* *} \\
(42.18 \%)\end{array}$ & $\begin{array}{c}4.68 \pm 0.30^{* *} \\
* \\
(60.89 \%)\end{array}$ & $\begin{array}{c}35.33 \pm 1.33^{* * * * *} \\
(65.08 \%)\end{array}$ & $\begin{array}{c}14.83 \pm 1.13^{* * * *} \\
(64.83 \%)\end{array}$ & $\begin{array}{c}1.82 \pm 0.21^{* * * *} \\
(71.06 \%)\end{array}$ & $1.83 \pm 0.16^{* * * *}$ & 76.62 \\
\hline
\end{tabular}

The results are expressed as mean \pm standard error of the mean (SEM). Probability values of ${ }^{* * * *} \mathrm{p}<0.0001,{ }^{* * *}$ $\mathrm{p}<0.001,{ }^{* *} \mathrm{p}<0.01$ and ${ }^{*} \mathrm{p}<0.05$ were compared with control. 
Estimation of M A in pyloricligation+NSAID induced stomach
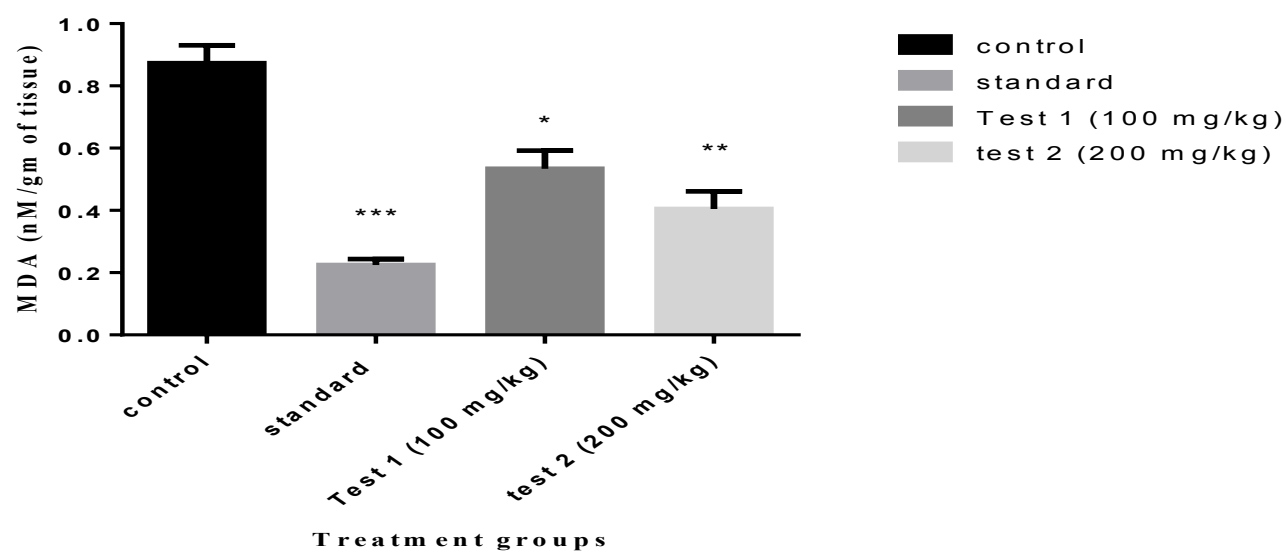

Figure 1 The results are expressed as mean \pm standard error of the mean (SEM). Probability values of ${ }^{* * * *} \mathrm{p}<$ $0.0001,{ }^{* * *} \mathrm{p}<0.001,{ }^{* *} \mathrm{p}<0.01$ and $^{*} \mathrm{p}<0.05$ were compared with control.

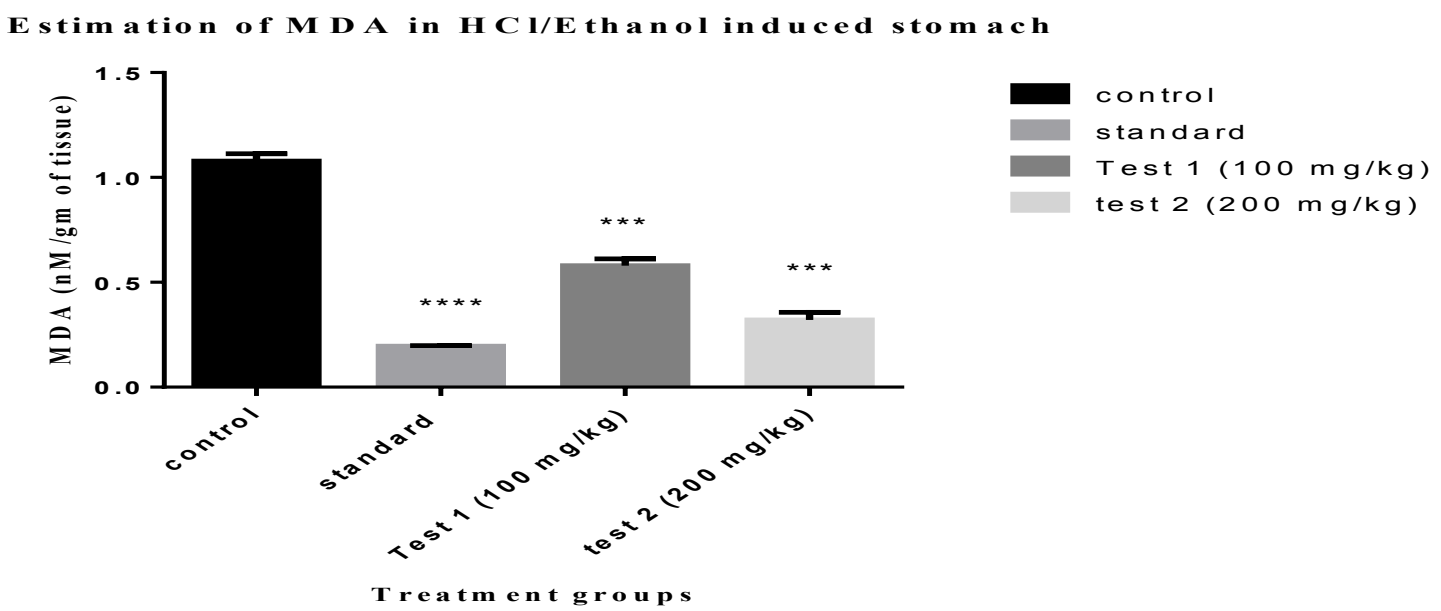

Figure 2: The results are expressed as mean \pm standard error of the mean (SEM). Probability values of ${ }^{* * * *} \mathrm{p}<$ $0.0001,{ }^{* * *} \mathrm{p}<0.001,{ }^{* *} \mathrm{p}<0.01$ and $^{*} \mathrm{p}<0.05$ were compared with control.

\section{Estimation CAT in pylorus ligation + aspirin induced ulcer model}

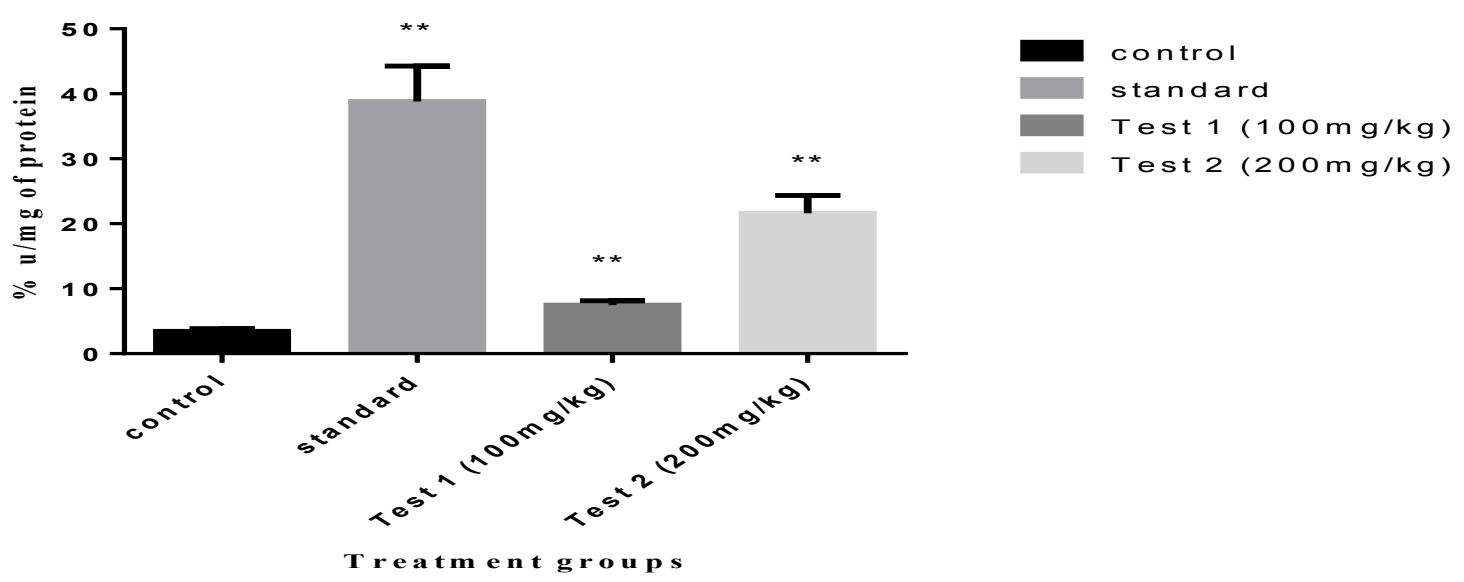

Fig-3: The results are expressed as mean \pm standard error of the mean (SEM). Probability values of ${ }^{* * * *} p<$ $0.0001,{ }^{* * *} p<0.001,{ }^{* *} p<0.01$ and $^{*} p<0.05$ were compared with control. 


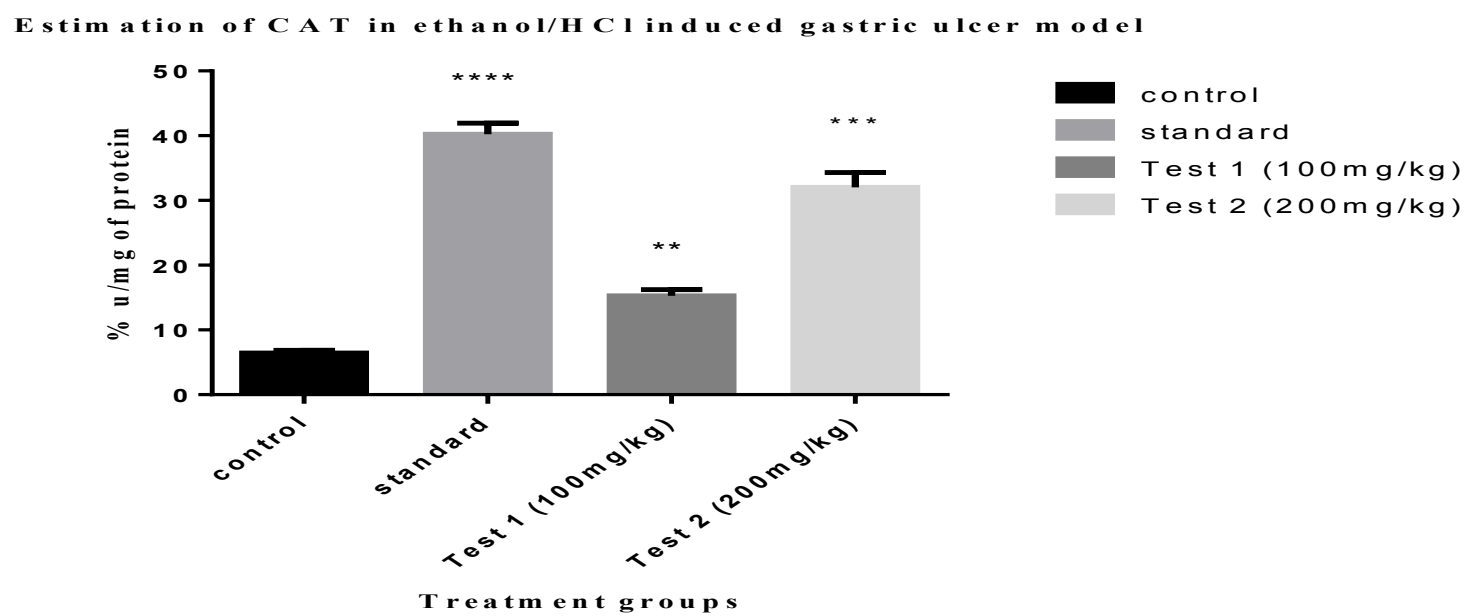

Fig-4: The results are expressed as mean \pm standard error of the mean (SEM). Probability values of ${ }^{* * * *} p<$ $0.0001,{ }^{* * *} p<0.001,{ }^{* *} p<0.01$ and ${ }^{*} p<0.05$ were compared with control.

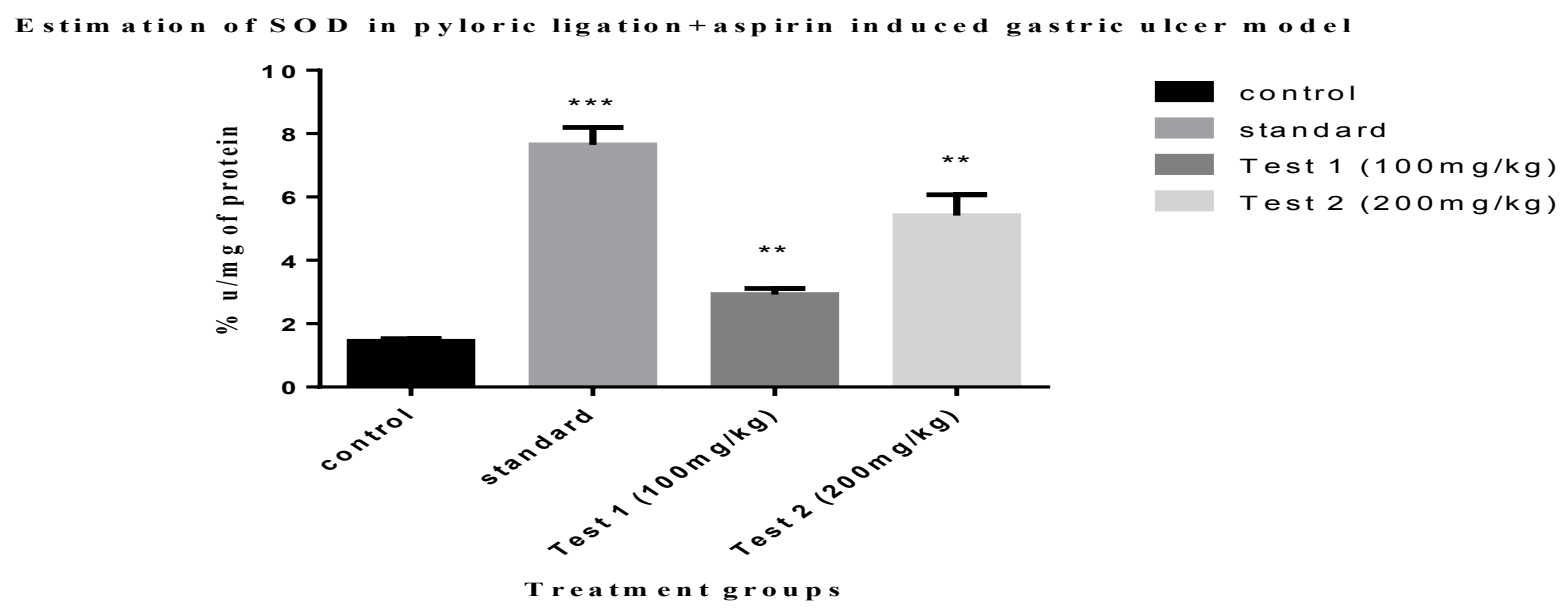

Fig-5: The results are expressed as mean \pm standard error of the mean (SEM). Probability values of ${ }^{* * * *} p<$ $0.0001,{ }^{* * *} p<0.001,{ }^{* *} p<0.01$ and $^{*} p<0.05$ were compared with control.

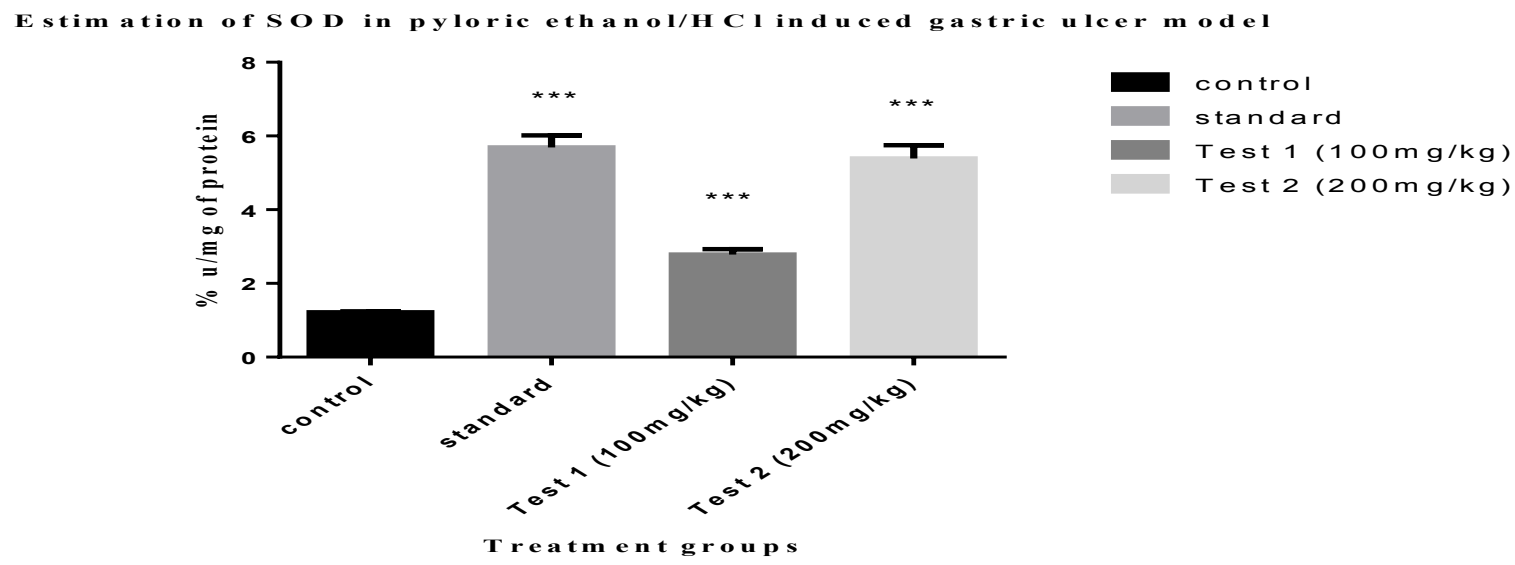

Fig-6: The results are expressed as mean \pm standard error of the mean (SEM). Probability values of ${ }^{* * * *} p<$ $0.0001,{ }^{* * *} p<0.001,{ }^{* *} p<0.01$ and ${ }^{*} p<0.05$ were compared with control. 


\section{Histopathological Examination:}

Figure 7: Histopathological evaluation of antiulcer activity of EA-MECC against pylorus ligation + aspirin induced ulcer model in rats (H\&E stain)

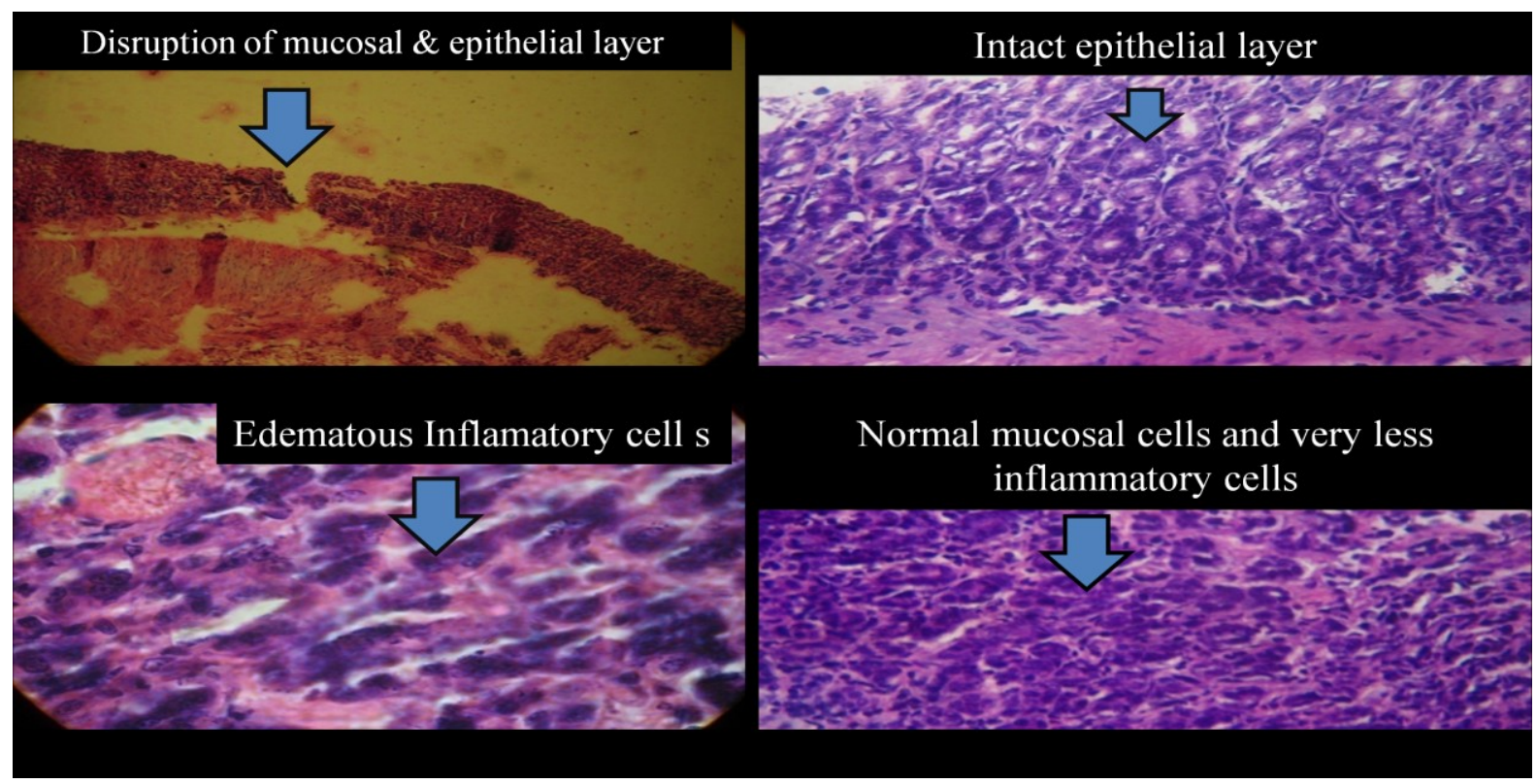

(A) CONTROL: Showing mucosal layer damage, disruption of epithelial tissue layer

(B) STANDARD: Intact epithelial layer

(C) TEST 1(100mg/kg): Presence of inflammatory cell and cells showing oedema formation

(D) TEST 2(200mg/kg): Showing normal mucosal cells and very less inflammatory cells

Figure 8: Histopathological evaluation of antiulcer activity of EA-MECC against $\mathrm{HCl}+$ Ethanol induced ulcer induced model in rats (H\&E stain).

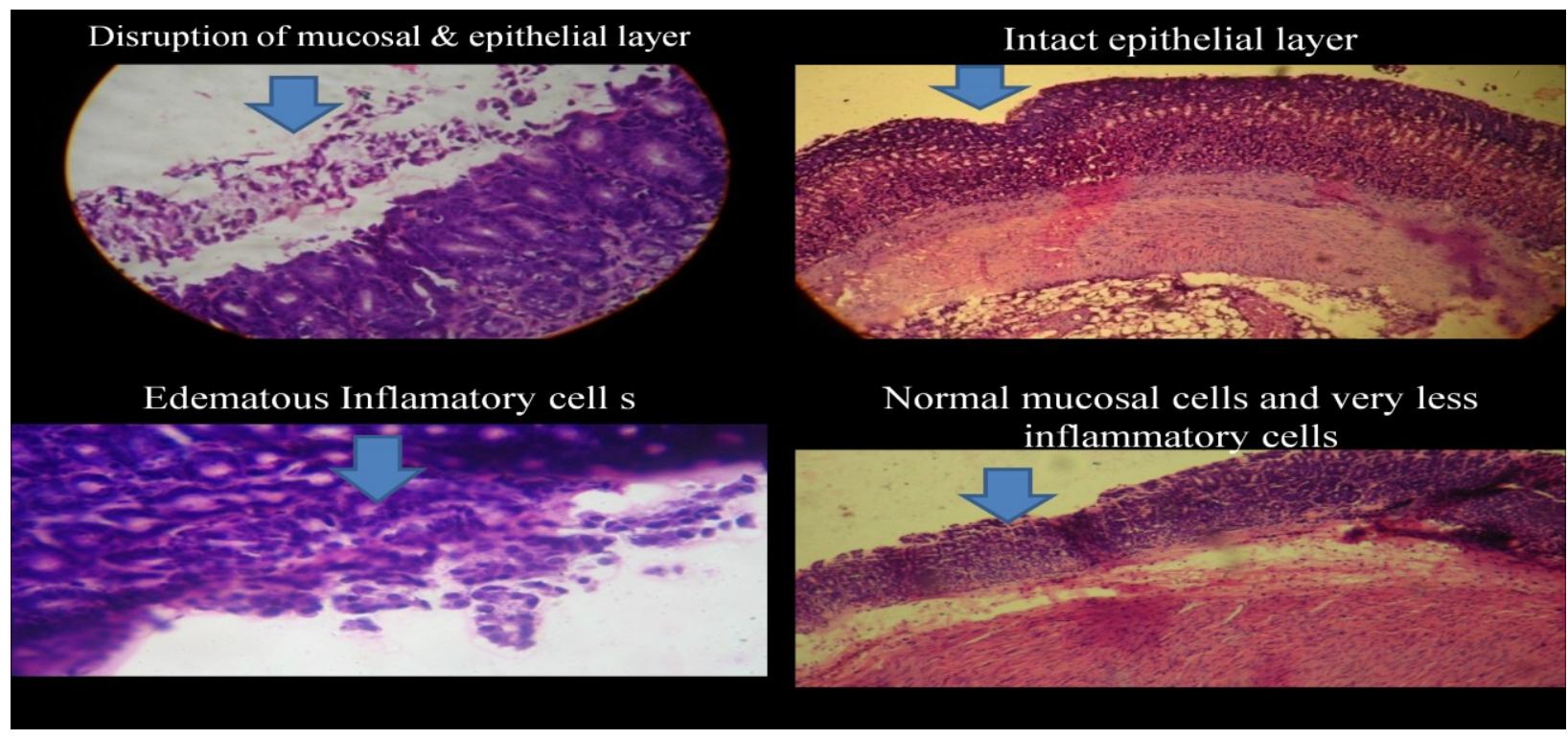

(A) CONTROL: Showing mucosal layer damage, disruption of epithelial tissue layer

(B) STANDARD: Intact mucosal layer

(C) TEST $1(100 \mathrm{mg} / \mathrm{kg})$ : Presence of inflammatory cell and cells showing oedema formation

(D) TEST 2(200mg/kg): Showing normal mucosal layer without major disruptions. 